\title{
Investigation of Possible Oxidative Damage Caused by Formaldehyde Exposure in the Rat's Heart and Aorta Tissue
}

\author{
Investigación de Posible Daño Oxidativo Causado por la Exposición \\ al Formaldehído en el Corazón de la Rata y Tejido de la Aorta
}

Rabia Tasdemir'1 Esra Acar²; Tuncay Colak ${ }^{3}$; Fatih Hunc²; Belgin Bamac ${ }^{3}$ Hale Maral Kır² \& Fatma Ceyla Eraldemir ${ }^{2}$

TASDEMIR, R.; ACAR, E.; COLAK, T.; HUNC, F.; BAMAC, B.; KIR, H. M. \& ERALDEMIR, F. C. Investigation of possible oxidative damage caused by formaldehyde exposure in the rat's heart and aorta tissue. Int. J. Morphol., 39(4):1042-1047, 2021.

SUMMARY: Formaldehyde (FA) is a toxic substance used frequently in the field of medicine as well as in many industrial areas. Especially people working in the field of anatomy, histology, and pathology are in high risk group because of the use of the FA. Studies showing the effects of FA on the cardiovascular system are few in number. The purpose of the present study was to investigate the effects of FA exposure, which we believe can cause oxidative stress, on the heart and aorta with various biochemical analyses. A total of 24 Wistar Albino rats were used in our study. We divided the rats into 3 groups as the Control Group (CG), the group exposed to low-dose FA (avg. 1ppm) (DDG) Group, and the group exposed to high-dose FA (avg. 10ppm) (YDG). At the end of the subchronic FA exposure, the blood samples, heart and aorta tissues of the rats were taken and subjected to biochemical analyses. As a result of the analyses, statistically significant differences were detected between CG $(2.96 \pm 0.85 \mathrm{ng} / \mathrm{mg})$, and HDG $(2.08 \pm 0.77 \mathrm{ng} / \mathrm{mg}) \mathrm{in}$ aortic tissues in TXNIP analysis $(\mathrm{p}<0.05)$. In heart tissues, significant differences were detected between CG $(0.73 \pm 0.27 \mathrm{ng} / \mathrm{mg})$ and LDG $(1.13 \pm 0.22$ $\mathrm{ng} / \mathrm{mg})(\mathrm{p}<0.05)$. Statistically significant differences were also detected between CG $(1.98 \pm 0.31 \mathrm{mM} / \mathrm{ml})$ and YDG $(2.43 \pm 0.31 \mathrm{mM} / \mathrm{ml})$ in serum MDA analyses $(\mathrm{p}<0.05)$. It was shown that subchronic application of FA to LDG rats through inhalation had no effects on apoptosis markers in heart tissues. More studies are required to show FA toxicity and the mechanism of action of pathology on the cardiovascular system. We believe that our study will contribute to clarifying the roles of mild and subchronic exposure of FA in heart and aortic tissues in terms of oxidative stress risk.

KEY WORDS: Formaldehyde; Heart; Aorta; Biochemistry.

\section{INTRODUCTION}

Formaldehyde (FA) is one of the preferred reactive aldehydes in the production of products, which make our lives easier offering comfort, as well as in the field of health. Formaldehyde has widespread use in anatomy, histology and pathology departments in medicine with the objective to protect tissue. For this reason, employees in these departments are in risk of FA exposure. The International Cancer Research Agency classified the FA as Group 1 Cancerogenic in June 2004 based on cohort studies (Liu et al., 2011).

Formaldehyde can trigger oxidative stress by increasing the formation of Reactive Oxygen Species (ROS), and for this reason, some secondary toxic effects in cardiac cells and tissues (Wu et al., 2017). ROS can cause oxidative damage and lipid peroxidation by interacting with DNA and lipids, including the activation of oxidases and inhibition of scavenging systems (Li et al., 2007).

ROS plays roles in the pathogenesis of atherosclerosis, reperfusion damage, hypertension, heart failure, and in apoptosis and the necrosis of myocytes depending on the increased ROS oxidative stress in the cardiovascular system. Ischemia-mediated ROS production is important for the activation of inflammatory signals in the myocardium (Wu et al.). ROS is produced in the inflammatory process, which performs oxidative modification of low-density lipoprotein causing structural damage and dysfunction of endothelial cells. ROS can also damage vascular endothelia and causing re-vascularization.

\footnotetext{
${ }^{1}$ Department of Anatomy, Faculty of Medicine, Gaziantep Islam Science and Tecnology University, Gaziantep, Turkey.

${ }^{2}$ Department of Biochemistry, Faculty of Medicine, Kocaeli University, Kocaeli, Turkey.

${ }^{3}$ Department of Anatomy, Faculty of Medicine, Kocaeli University, Kocaeli, Turkey.

Our study was supported by Kocaeli University, Scientific Research Projects Unit with the project number 2016/078.
} 
Thioredoxin-Interacting Protein (TXNIP) is a prooxidant protein inactively modulating the activity of ThioredoxinReductase (Trx) and antioxidant function. TXNIP binds to the active area of Trx, inhibiting the disulfide reductase activity; and is therefore known as endogenous Trx inhibitor.

Myeloperoxidase (MPO) is used as a biological marker for neutrophil infiltration; and is stored as a lysosomal protein. It forms Hypochlorous Acid ( $\mathrm{HOCl}$ ) by using $\mathrm{H} 2 \mathrm{O} 2$ and chloride anions (Cl-) (Davies \& Hawkins, 2020).

Hydroxyproline is an amino acid with structural and physiological importance. The oxidation of hydroxyproline with Hydroxyproline Oxidase (OH-POX) plays important roles in antioxidative reaction, survival, and homeostasis of the cell (Wu et al.). In the present study, the purpose was to investigate Hydroxyproline levels to understand the damage FA might cause in structural terms to aortic and heart tissues and its relations with antioxidant parameters. Also, lipid peroxidation products are usually measured as an indicator of ROS-mediated damage to tissues. Since formaldehyde causes oxidative stress, it is important to measure the Malondialdehyde (MDA) as a marker of in vivo lipid peroxidation status (Kum et al., 2007).

Although there are many studies showing that formaldehyde has negative effects on the respiratory system, nervous system, and digestive system, studies that show its effects on the cardiovascular system are few in number. In the present study, the purpose was to investigate the effects of subchronic exposure of FA, which we believe may cause oxidative stress, at different doses to the heart and aorta with various biochemical analyses.

\section{MATERIAL AND METHOD}

The present study was commenced after the approval of Kocaeli University Animal Experiments Local Ethics Committee was received on 20.10.2016 with the number 6/ 1 - 2016.

The Wistar Albino rats that were used in the experiment were obtained from Kocaeli University Experimental Medicine Research and Application Unit. A total of 24 six-month-old female Wistar Albino rats were used in the study (Katsnelson et al., 2013). Rats were allowed to live freely in cages in 12-hour light and 12-hour dark environment. The environment where the cages were located was supported with air-conditioned system at an average temperature of $20^{\circ} \mathrm{C}$ and an average humidity of $20-40 \%$.
Rats were fed with normal pellet feed and drinking water. Before the experiment was commenced, the weights of the rats were measured as an average of $254.42 \pm 13.25 \mathrm{~g}$. The weight measurements of the rats were repeated at the same time on the same day each week during the 12-week period. Each animal's tail was painted with a different color after the measurements to avoid the confusion of the animals when measuring weights. Physical activity and appearance of the rats were constantly monitored throughout the FA exposure.

The rats were selected randomly, and divided into 3 groups with 8 animals in each group. The first group was identified as the Control Group, and normal air inhalation was ensured. The second group were exposed to low-dose FA at an average of 1 ppm 5 days a week 4 hours every day throughout 12 weeks. The third group rats inhaled an average high-dose FA of $10 \mathrm{ppm}$, providing that for the same periods (Katsnelson et al.).

In the present experiment, we implemented subchronic FA exposure to rats in line with "OECD Guideline for the Testing of Chemicals" Protocol that was published in 2009 by the Organization for Economic Co-operation and Development (Organisation for Economic Cooperation and Development, 2009).

Experimental setup: A glass cabinet of $100 \mathrm{~cm} * 70 \mathrm{~cm} * 35$ $\mathrm{cm}$ was used for the experiment in the study. The inside of the cabin was separated with a glass compartment as $20 \mathrm{~cm}$ $80 \mathrm{~cm}$. A $6 \mathrm{~cm}$-diameter hole was drilled in the middle compartment to let air pass. Another $6 \mathrm{~cm}$ diameter hole was drilled into the glass wall on the outer wall of the larger compartment along with a plastic pipe to eliminate the FAdense air from the cabin. A cover that could be opened from the top separately was inserted for both compartments of the cabin to ensure air flow. The experimental animals were placed in the cabinet in this setting (Matsuoka et al., 2010) (Fig. 1). Experiments were performed for one week in the empty cage to ensure the optimization of the amount of formaldehyde and to test the availability of the setting and the cabin. Two drops of FA were dripped on a napkin to ensure low-dose FA exposure in the small section, and 9 drops of FA were dripped on a napkin to ensure high-dose FA exposure. A Honeywell ToxiRAE PRO (HCHO) brand Dosimeter was placed in the large compartment to monitor the rats and the amount of FA inside the cabin. The program of the Dosimeter was installed on the computer, and the amount of FA was tracked and recorded during the experiment on the computer, and evaluations were made objectively to determine whether we created a high-dose and low-dose FA with an average dose. We calibrated the Dosimeter every day before the experiments were initiated to make FA measurements reliable. 


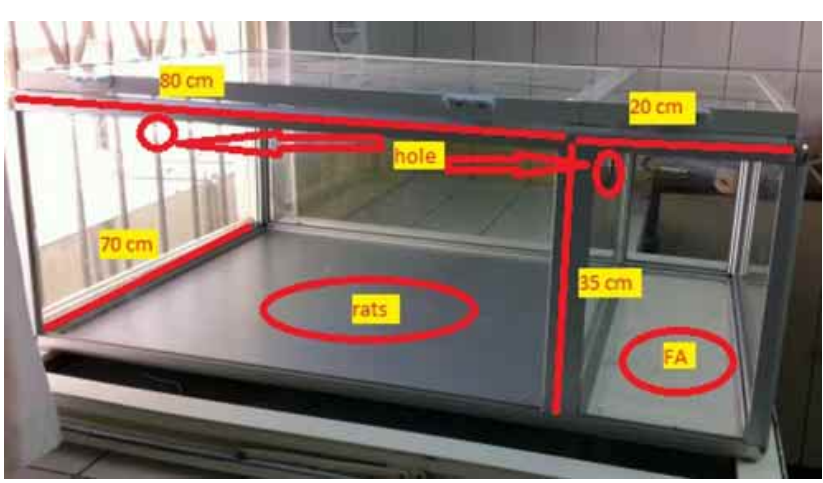

Fig. 1. Cabinet used for experimentation. The FA vapour in the small compartment passes through the $6 \mathrm{~cm}$ diameter hole in between to the part where the rats are located. The FA concentration is measured by the dosimeter in the section where the rats are located.

At the end of the 12-week experiment, the rats were sacrificed after anesthesia with intraperitoneal (ip) $6 \mathrm{mg} / \mathrm{kg}$ xylazine hydrochloride (Rompun, Bayer, Istanbul, Turkey) and $30 \mathrm{mg} / \mathrm{kg}$ ketamine hydrochloride (Ketalar, Parke-Davis, Istanbul, Turkey). We worked hard to avoid that the rats did not feel pain. The blood and tissues of the rats were taken for biochemical analysis. TXNIP protein and MPO and Hydroxyproline enzyme were examined with Elisa Technique in aortic and heart tissues. Also, TXNIP, MPO, MDA, Hydroxyproline, and Triglycerides were determined in the plasma.

Biochemical analysis: Blood samples $(2.5 \mathrm{~mL})$ were taken from each animal, and serum samples were obtained after centrifuging for 10 minutes at 2200xg (NF 800R Nüve, Turkey). Serum samples were stored at $-40{ }^{\circ} \mathrm{C}$. The aorta and the heart were washed with saline solution $(0.09 \% \mathrm{NaCl})$ to remove contaminating blood. The aorta and the heart were weighed, and were then homogenized with saline with 1/10 phosphate buffer (PBS; $50 \mathrm{mM}$, pH 7.4) and homogenizer (T25 Basic Ultra Turrax, IKA WERKE, Deutschland (Germany)) at $24.000 \mathrm{rpm}$. The homogenates were centrifuged for 15 minutes at $10.000 \mathrm{xg}$ at $4{ }^{\circ} \mathrm{C}$. These homogenates that were divided into small tubes were stored for tissue-based measurements.
The protein determination, which is required for proportional calculation of the measurements for tissue homogenates, was made according to the modified Lowry Method (Hartree, 1972).

Serum MDA concentrations were determined with Buege and Aust Method (Buege \& Aust, 1978). Briefly, MDA was incubated at $100{ }^{\circ} \mathrm{C}$ for 15 minutes, and reacted with thiobarbituric acid. Serum MDA levels were measured spectrophotometrically in the supernatant as $535 \mathrm{~nm}$. The tissues MPO (Layer no: 201-11-0575), Hydroxyproline (Layer no: 201-11-0512), and TXNIP (Layer no: 201-111181) concentrations were measured with sandwich EnzymeLinked Immunosorbent Trial (ELISA) technique (Sunred Biological Technology Co., China) following the instructions of the manufacturer of ELISA kits.

Statistical analyses were made with IBM SPSS 20.0 (SPSS Inc, Chicago, IL, USA). Whether the data matched normal distribution was examined with the KolmogorovSmirnov Test. The Mann Whitney-U Test was used for variables that matched the normal distribution, and the Tukey HSD was done to find out which group caused the difference. The Kruskal Wallis Test was applied for variables that did not match normal distribution. The results are given as mean \pm standard deviation (SD), median (25-75\%), and minimum-maximum values. Statistical significance was assumed at $\mathrm{P}<0.05$.

\section{RESULTS}

The difference between the groups was statistically significant $(\mathrm{p}<0.05)$ in TXNIP analysis made in aortic tissue homogenate. A statistically significant difference was detected between the Control Group $(2.96 \pm 0.85 \mathrm{ng} / \mathrm{mg})$ and high-dose FA Group $(2.08 \pm 0.77 \mathrm{ng} / \mathrm{mg})(\mathrm{p}<0.05)$ (Table I). Decreased TXNIP values were detected in the group exposed to FA. Although there were no statistical differences, there were differences between low-dose group and high-dose group average values. Significant differences were detected for heart

Table I. Heart and aorta tissue TXNIP, Hydroxyproline and MPO levels.

\begin{tabular}{|c|c|c|c|c|c|c|c|}
\hline & & \multicolumn{2}{|c|}{ TXNIP (ng/mg) } & \multicolumn{2}{|c|}{ Hydroxyproline(ng/mg) } & \multicolumn{2}{|c|}{ MPO (ng/mg) } \\
\hline & & \multirow{3}{*}{ Mean \pm SD } & \multirow{3}{*}{$\begin{array}{l}\text { Median } \\
\text { Min.-Max. }\end{array}$} & \multirow{3}{*}{ Mean \pm SD } & \multirow{3}{*}{$\begin{array}{c}\text { Median } \\
\text { Min.-Max. }\end{array}$} & \multirow{3}{*}{ Mean \pm SD } & Median \\
\hline & & & & & & & \multirow{2}{*}{ Min.-Max. } \\
\hline & & & & & & & \\
\hline & CG & $0.73 \pm 0.27 *$ & $0.73,0.24-1.06$ & $0.79 \pm 0.15$ & $0.82,0.61-0.91$ & $0.37 \pm 0.03$ & $0.38,0.33-0.41$ \\
\hline \multirow[t]{3}{*}{ HEART } & LDG & $1.13 \pm 0.22 *$ & $1.17,0.72-1.34$ & $0.85 \pm 0.40$ & $0.71,0.64-1.75$ & $0.63 \pm 0.45$ & $0.39,0.26-1.46$ \\
\hline & HDG & $1.03 \pm 0.17^{*}$ & $1.03,0.74-1.30$ & $0.76 \pm 0.20$ & $0.76,0.43-1.04$ & $0.51 \pm 0.14$ & $0.49,0.33-0.72$ \\
\hline & CG & $2.96 \pm 0.85^{*}$ & $3.04,1.35-3.74$ & $5.33 \pm 0.78$ & $5.67,4.17-5.80$ & $4.64 \pm 1.42$ & $5.22,2.54-5.60$ \\
\hline \multirow[t]{2}{*}{ AORTA } & LDG & $2.36 \pm 0.55^{*}$ & $2.25,1.72-3.13$ & $3.62 \pm 2.46$ & $2.29,1.19-6.83$ & $3.16 \pm 0.86$ & $3.01,2.41-4.62$ \\
\hline & HDG & $2.08 \pm 0.77 *$ & $1.94,1.10-3.45$ & $1.99 \pm 0.61$ & $2.10,1.09-2.89$ & $4.15 \pm 2.29$ & $3.50,2.67-9.26$ \\
\hline
\end{tabular}


tissues between the Control Group $(0.73 \pm 0.27 \mathrm{ng} / \mathrm{mg})$ and lowdose FA group $(1.13 \pm 0.22 \mathrm{ng} / \mathrm{mg})(\mathrm{p}<0.005)$. The TXNIP values increased in the group exposed to FA (Table I).

The difference between groups regarding the serum TXNIP and plasma triglyceride values was not statistically significant. However, mean triglyceride levels differed between the groups (Table II). This may be the proof that TXNIP triggers lipolysis.
Statistically significant differences were detected between the Control Group $(1.98 \pm 0.31 \mathrm{mM} / \mathrm{ml})$ and the highdose FA group $(2.43 \pm 0.31 \mathrm{mM} / \mathrm{ml})$ in serum MDA analysis $(\mathrm{p}<0.05)$ (Table II). Differences were detected with the lowdose FA group, although not at statistically significant levels when the averages were compared. No statistically significant differences were detected in terms of other parameters.

Table II. Serum MDA, TXNIP, Hydroxyproline, MPO and plazma triglyceride levels.

\begin{tabular}{|c|c|c|c|c|c|c|}
\hline \multirow{4}{*}{ 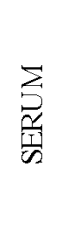 } & & $\begin{array}{c}\text { MDA }(\mu \mathrm{M} / \mathrm{ml}) \\
\text { Mean } \pm \text { SD }\end{array}$ & $\begin{array}{c}\mathrm{TXNIP}(\mu \mathrm{M} / \mathrm{ml}) \\
\text { Mean } \pm \mathrm{SD}\end{array}$ & $\begin{array}{l}\text { TRIGLYCERIDE } \\
\qquad \begin{array}{c}(\mu \mathrm{M} / \mathrm{ml}) \\
\text { Mean } \pm \mathrm{SD}\end{array}\end{array}$ & $\begin{array}{l}\text { Hydroxyproline } \\
\qquad(\mu \mathrm{M} / \mathrm{ml}) \\
\text { Mean } \pm \mathrm{SD}\end{array}$ & $\begin{array}{c}\mathrm{MPO}(\mu \mathrm{M} / \mathrm{ml}) \\
\text { Mean } \pm \mathrm{SD}\end{array}$ \\
\hline & $\mathrm{CG}$ & $1.98 \pm 0.31 *$ & $0.67 \pm 0.24$ & $41.00 \pm 11.39$ & $45.13 \pm 18.33$ & $2.84 \pm 0.65$ \\
\hline & LDG & $2.30 \pm 0.47$ & $0.91 \pm 0.28$ & $45.63 \pm 6.41$ & $60.93 \pm 17.92$ & $2.44 \pm 0.39$ \\
\hline & HDG & $2.43 \pm 0.31 *$ & $0.85 \pm 0.25$ & $48.69 \pm 16.57$ & $57.41 \pm 12.83$ & $2.52 \pm 0.99$ \\
\hline
\end{tabular}

$* \mathrm{p}<0.05$

\section{DISCUSSION}

Cellular metabolism and oxidative stress are the processes that are associated with a wide range of pathological conditions in the heart, including mitochondria and ischemia-reperfusion damage. TXNIP, which is the antioxidant Thioredoxin and endogenous inhibitor that exists in every tissue, emerges as a key association between mitochondrial function regulation and cellular redox balance.

There is increasing evidence showing that TXNIP plays very important roles in cardiovascular disorders acting as a sensor for oxidative stress. Recently, Schulze et al. (2004) reported that hyperglycemia induces TXNIP in vascular flat muscle cells, inhibits the antioxidant function of Thioredoxin, and increases oxidative stress. Yoshioka et al. (2004), on the other hand, reported that TXNIP expression decreased in cardiac hypertrophy, and then, cardiac cell growth that was induced by Thioredoxin was stimulated. These results support the opinion that TXNIP is a critical regulator of biochemical signaling in cardiovascular disorders. Also, it was shown that Platelet-Derived Growth Factor (PDGF) Thioredoxin suppresses TXNIP expression with the increases in DNA synthesis and activity in vascular flat muscle cells (Schulze et al.). However, it was also shown that excessive TXNIP expression eliminates the DNA synthesis and the activity of Thioredoxin induced by PDGF. These results show that TXNIP has pro-apoptotic effects in VSMCs over the suppression of Thioredoxin activity. It has been recently found that exposure to physiological fluid shift stress in the endothelial of the healthy rabbit aorta ( $12 \mathrm{dyn} /$ $\mathrm{cm}^{2}$ for 24 hours) reduced TXNIP expression increasing
Thioredoxin activity. It was also shown that physiological flow, JNK, p38 and Vascular Cell Adhesion Molecule 1 (VCAM1) expression in aortic endothelial cells inhibit tumor necrosis factor stimulation (Yamawaki et al., 2003).

Increased TXNIP levels in heart tissues and parallels increased serum MDA levels show that heart tissues become more susceptible to oxidative stress in rats exposed to Formaldehyde.

In previous studies, oxidative stress was reported to be closely associated with cell apoptosis. It was shown that exposure to FA also increased lipid peroxidation suppressing the antioxidant system, and causing oxidative stress (Wu et al.).

Previous studies also showed that TXNIP deficiency or suppressed TXNIP gene expression was protective against diabetic nephropathy, myocardial ischemia / reperfusion damage, affecting the regulation of pro-apoptotic pathways, and protecting against kidney autophagy (Shah et al., 2015).

However, TXNIP concentrations were not investigated before in heart and aortic tissues along with oxidative stress markers, which may increase depending on the FA. TXNIP is a metabolism regulator and an inhibitor of antioxidant Thioredoxin; however, little is known about their roles in myocardium.

It is known that ROS production, which is caused by oxidative stress and high glucose, plays key roles in the 
progression of diabetic cardiovascular disease and cardiomyocytesproptosis. A study conducted on diabetic rats showed that increased TXNIP production in cardiac endothelium resulted in higher ROS production, lower nuclear b-catenin expression, and therefore, impaired angiogenesis. It was reported in the same study that increased expression of TXNIP limited the angiogenesis and indicated a poor prognosis after Myocardial Infarction (MI) in diabetes (Shen et al., 2018).

In a study conducted on humans, it was reported that oxidative stress increases TXNIP levels, but TXNIP2, which is one of the isoforms of TXNIP, can cause acute MI (Zhang et al., 2018).

Many studies provide evidence that Insulin Resistance (IR) causes cardiac dysfunction and myocardial cell death (Maneechote et al., 2019). Hydroxyproline, which is a collagen synthesis index, was found to have increased in heart tissues in Type 2 diabetic rats. It was also reported that diabetes increases myocardial collagen Type I and Type III in animals (Yang \& Peng, 2010). In another study, IR did not affect hydroxyproline levels (Coskun et al., 2021). Also, it was found that hydroxyproline content was significantly higher in rats with heart failure (Uray et al., 2020). In our study, collagen level hydroxyproline was examined to measure the damage of FA in aortic and heart tissues. However, no significant differences were detected in this respect. We believe that our results may have occurred because of the form and duration of exposure to FA.

There are studies reporting that there were increases in MDA levels of animals in the group exposed to intraperitoneal (ip) and intragastric (ig) high-dose FA (Wu et al.). It was also reported that MDA and other oxidative stress markers increased in a dose-dependent manner (Songur et al., 2008). In our study, increased serum TXNIP and plasma triglycerides and MDA levels in low-dose FA group shows that it was released into the serum because of the increased amount of tissue oxidants, but not at significant levels because they were exposed to low-dose formaldehyde inhalation. Since there are no studies that investigated MDA, TXNIP, and MPO values because of FA exposure in heart and aorta tissues, we did not have a chance to compare our results.

Increased MPO activity can modulate the production of oxidant molecules, and finally, the tissue damage under oxidative stress conditions. It was shown in a previous study that changes in MPO activity after FA exposure were not at significant levels; however, another study reported that there were significant increases in MPO activity in lung, liver, and kidney tissues (Aydemir et al., 2017). It was reported in another study that MPO activity levels decreased with FA exposure in all groups compared to the Control Group (Bakar et al., 2015). In our study, the MPO levels tended to decrease in rats that inhaled FA compared to the Control Group. The fact that our results were not compatible with the literature data may be associated with the acute and chronic effects of the FA might vary depending on the form, dose, and duration of exposure.

As a conclusion, it was shown that low-dose subchronic FA application to rats through inhalation did not affect apoptosis markers in heart tissues. More long-term studies are required to show the FA toxicity and its action mechanism of organ pathology in tissues far from the respiratory tract. The present study is especially important in terms of illuminating the roles of mild and subchronic exposure to FA in heart and aortic tissues for oxidative stress risk.

TASDEMIR, R.; ACAR, E.; COLAK, T.; HUNC, F.; BAMAC, B.; KIR, H. M. \& ERALDEMIR, F. C. Investigación de posible daño oxidativo causado por la exposición al formaldehído en el corazón de la rata y tejido de la aorta. Int. J. Morphol., 39(4):10421047, 2021.

RESUMEN: El formaldehído es una sustancia tóxica que se utiliza con frecuencia en el campo de la medicina, así como en muchas áreas industriales. Especialmente las personas que trabajan en el area de la anatomía, y patología se encuentran en el grupo de alto riesgo debido al uso de esta sustancia. Pocos son los estudios que muestran los efectos del formaldehído en el sistema cardiovascular. El propósito del presente estudio fue investigar a través de análisis bioquímicos, los efectos de la exposición a formaldehído, que podría causar estrés oxidativo, en el corazón y la aorta. Se utilizaron un total de 24 ratas Albinas Wistar. Dividimos a las ratas en 3 grupos: grupo control (GC), grupo expuesto a dosis bajas de AG (promedio $1 \mathrm{ppm}$ ) (DDG) y grupo expuesto a dosis altas de AG (promedio $10 \mathrm{ppm}$ ) (YDG). Al término de la exposición a FA subcrónica, se tomaron muestras de sangre, tejido cardíaco y aorta de las ratas y se sometieron a análisis bioquímicos. Como resultado de los análisis, se detectaron diferencias estadísticamente significativas entre GC $(2,96 \pm 0,85$ $\mathrm{ng} / \mathrm{mg})$ y HDG $(2,08 \pm 0,77 \mathrm{ng} / \mathrm{mg})$ en los tejidos aórticos en el análisis TXNIP $(\mathrm{p}<0,05)$. En los tejidos cardíacos se detectaron diferencias significativas entre GC $(0,73 \pm 0,27 \mathrm{ng} / \mathrm{mg})$ y LDG $(1,13$ $\pm 0,22 \mathrm{ng} / \mathrm{mg})(\mathrm{p}<0,05)$. También se detectaron diferencias estadísticamente significativas entre CG $(1,98 \pm 0,31 \mathrm{mM} / \mathrm{ml})$ y YDG $(2,43 \pm 0,31 \mathrm{mM} / \mathrm{ml})$ en los análisis de MDA en suero (p $<0,05)$. Se demostró que la aplicación subcrónica de formaldehído a ratas LDG a través de la inhalación no tuvo efectos sobre los marcadores de apoptosis en los tejidos del corazón. Se requieren más estudios para demostrar la toxicidad de los AG y el mecanismo de acción de la patología en el sistema cardiovascular. Creemos que nuestro estudio contribuirá a aclarar las funciones de la exposición leve y subcrónica de formaldehído en los tejidos cardíacos y aórticos en términos de riesgo al estrés oxidativo.

PALABRAS CLAVE: Formaldehído; Corazón; Aorta; Bioquímica. 


\section{REFERENCES}

Aydemir, S.; Akgün, S. G.; Beceren, A.; Yuksel, M.; Kumas, M.; Erdogan, N.; Sardas, S. \& Omurtag, G. Z. Melatonin ameliorates oxidative DNA damage and protects against formaldehyde-induced oxidative stress in rats. Int. J. Clin. Exp. Med., 10(4):6250-61, 2017.

Bakar, E.; Ulucam, E. \& Cerkezkayabekir, A. Investigation of the protective effects of proanthocyanidin and vitamin $E$ against the toxic effect caused by formaldehyde on the liver tissue. Environ. Toxicol., 30(12):1406$15,2015$.

Buege, J. A. \& Aust, S. D. Microsomal lipid peroxidation. Methods Enzymol., 52:302-10, 1978.

Coskun, Z. M.; Beydogan, A. B.; Yanar, K.; Atukeren, P. \& Bolken, S. Oxidative stress and inflammatory response of ghrelin on myocardial and aortic tissues in insulin-resistant rats. J. Pharm. Pharmacol., 73(1):692-9, 2021.

Davies, M. J. \& Hawkins, C. L. The role of myeloperoxidase in biomolecule modification, chronic inflammation, and disease. Antioxid. Redox Signal., 32(13):957-81, 2020.

Hartree, E. F. Determination of protein: a modification of the Lowry method that gives a linear photometric response. Anal. Biochem., 48(2):422-7, 1972.

Katsnelson, B. A.; Degtyareva, T. D.; Privalova, L. I.; Minigaliyeva, I. A.; Slyshkina, T. V.; Ryzhov, V. V. \& Beresneva, O. Y. Attenuation of subchronic formaldehyde inhalation toxicity with oral administration of glutamate, glycine and methionine. Toxicol. Lett., 220(2):181-6, 2013.

Kum, C.; Sekkin, S.; Kiral, F. \& Akar, F. Effects of xylene and formaldehyde inhalations on renal oxidative stress and some serum biochemical parameters in rats. Toxicol. Ind. Health, 23(2):115-20, 2007.

Li, H.; Wang, J.; König, R.; Ansari, G. A. S. \& Khan, M. F. Formaldehydeprotein conjugate-specific antibodies in rats exposed to formaldehyde. J. Toxicol. Environ. Health A, 70(13):1071-5, 2007.

Liu, P.; Guo, J. \& Qi, Z. Formaldehyde suppresses neuronal apoptosis via inhibition of outward $\mathrm{K}(+)$ currents in rat hippocampus. Can. J. Physiol. Pharmacol., 89(11):837-44, 2011.

Maneechote, C.; Palee, S.; Apaijai, N.; Kerdphoo, S.; Jaiwongkam, T.; Chattipakorn, S. C. \& Chattipakorn, N. Mitochondrial dynamic modulation exerts cardiometabolic protection in obese insulin-resistant rats. Clin. Sci. (Lond.), 133(24):2431-47, 2019.

Matsuoka, T.; Takaki, A.; Ohtaki, H. \& Shioda, S. Early changes to oxidative stress levels following exposure to formaldehyde in ICR mice. $J$. Toxicol. Sci., 35(5):721-30, 2010.

Organisation for Economic Cooperation and Development (OECD). Proposal for a New Guldeline for OECD Guldelines for the Testing of Chemicals Bioaccumulation In Terrestrial Oligochaetes. Paris, Organisation for Economic Cooperation and Development, 2009. Available from: https://www.oecd.org/chemicalsafety/testing/ 44098118.pdf

Schulze, P. C.; Yoshioka, J.; Takahashi, T.; He, Z.; King, G. L. \& Lee, R. T. Hyperglycemia promotes oxidative stress through inhibition of thioredoxin function by thioredoxin-interacting protein. J. Biol. Chem., 279(29):30369-74, 2004

Shah, A.; Xia, L.; Masson, E. A. Y.; Gui, C.; Momen, A.; Shikatani, E. A.; Husain, M.; Quaggin, S.; John, R. \& Fantus, I. G. Thioredoxininteracting protein deficiency protects against diabetic nephropathy. $J$. Am. Soc. Nephrol., 26(12):2963-77, 2015.

Shen, M.; Bai, D.; Liu, B.; Lu, X.; Hou, R.; Zeng, C.; Li, N.; Fu, Z.; Li, C.; Tao, L.; et al. Dysregulated Txnip-ROS-Wnt axis contributes to the impaired ischemic heart repair in diabetic mice. Biochim. Biophys. Acta Mol. Basis Dis., 1864(12):3735-45, 2018.

Songur, A.; Sarsilmaz, M.; Ozen, O.; Sahin, S.; Koken, R.; Zararsiz, I. \& Ilhan, $\mathrm{N}$. The effects of inhaled formaldehyde on oxidant and antioxidant systems of rat cerebellum during the postnatal development process. Toxicol. Mech. Methods, 18(7):569-74, 2008.
Uray, K. S.; Peng, Z.; Cattano, D.; Eltzschig, H. K. \& Doursout, M. F. Development of pulmonary fibrosis after heart failure induced by elevated left atrial pressure. Am. J. Transl. Res., 12(8):4639-47, 2020.

Wu, D.; Jiang, Z.; Gong, B.; Dou, Y.; Song, M.; Song, X. \& Tian, Y. Vitamin E reversed apoptosis of cardiomyocytes induced by exposure to high dose formaldehyde during mice pregnancy. Int. Heart J., 58(5):76977, 2017.

Yamawaki, H.; Lehoux, S. \& Berk, B. C. Chronic physiological shear stress inhibits tumor necrosis factor-induced proinflammatory responses in rabbit aorta perfused ex vivo. Circulation, 108(13):1619-25, 2003.

Yang, Z. H. \& Peng, X. D. Effects of valsartan on diabetic cardiomyopathy in rats with type 2 diabetes mellitus. Chin. Med. J. (Engl.), 123(24):3640-3, 2010

Yoshioka, J.; Schulze, P. C.; Cupesi, M.; Sylvan, J. D.; MacGillivray, C.; Gannon, J.; Huang, H. \& Lee, R. T. Thioredoxin-interacting protein controls cardiac hypertrophy through regulation of thioredoxin activity. Circulation, 109(21):2581-6, 2004.

Zhang, Y.; Zhong, P.; Xu, Y.; Wang, B.; Zhu, T.; Zhang, W.; Wang, H.; Wei, Z. \& Huang, J. Differential expression of TXNIP isoforms in the peripheral leukocytes of patients with acute myocardial infarction. Dis. Markers, 2018:9051481, 2018.

\author{
Corresponding author: \\ Rabia Tasdemir \\ Department of Anatomy \\ Faculty of Medicine \\ Gaziantep Islam Science and Tecnology University \\ Gaziantep \\ TURKEY
}

E-mail: rabiatsdmr@gmail.com

Received: 23-03-2021

Accepted: 05-05-2021 